\title{
VI: Dialogic GenRes: Conversations AND Feuilletons
}

Whether my Moxevian spoke the truth or not I will not now enquire. And what business is it of mine? I merely mention in passing what I as a traveler heard from him. My one endeavor in this has been to give to his thoughts their own form (peri) and to his words his accent ( $k$ 'ilo). If I have succeeded in this I have fulfilled my intention. My Moxevian told me much more, but for various reasons it would not do to write down all his conversation. ... I will only say that in his own words he made me a sharer in his heart's woe. (Chavchavadze, Letters of a Traveler, VIII)

While Georgian Romantics sometimes represent the landscape of the Caucasus as a hypostasis of nature, a "natural world seemingly uninhabited by humans" (Ram and Shatirishvili 2004, 13), devoid in particular of human voices, by the 1870s the landscape described by Georgian travelers would seem incomplete without realistic transcriptions of the speech of the inhabitants, usually in the form of dialogues with the traveler himself. Practices of realistic transcription of peasant speech constitutive of the authenticity of folkloric texts (Umikashvili 1871) were also deployed by Chavchavadze that same year in his Letters of a Traveler (1871) to constitute the authenticity of these "dialogs with a peasant." Where Umikashvili locates the collection of folklore by transcription within a broader epistemic imperative to "get to know" the people, the genre of "dialogs with a peasant" displays this imperative in action. The people, after all, were not yet a public; the only way they could be addressed by the intelligentsia was in face-to-face dialogue, and the only way they could speak their minds to the intelligentsia was to have these conversations transcribed and printed in turn.

If quoted dialogues often taking the form of realistic portrayals of the speech of peasants formed a primary genre incorporated within the complex, heterogeneous assemblage of such genres of the secondary genre of the newspaper, it is also the case that the newspaper itself represents, as a whole, represents a kind of quoting dialogue between 
intelligentsia writers/readers of Droeba (I borrow this distinction from Inoue 2006, 111). Droeba, after all, is primarily composed of heterogeneous correspondence written by its readers. This correspondence is particularly found in the feuilleton section of the newspaper, forming the lower section of the page, which at least in the Droeba period is composed largely of occasional correspondence. All of Bavreli's correspondence, as well as much of the other material I consider in this book, including virtually all the examples of reported dialogues with peasants, was placed in this special, heterogeneous section of the newspaper. As we will see below in more detail, following a tendency that had long been observed in Russia (Morson 1981, 15-17, Dianina 2003ab), the feuilleton moves from denoting merely an exemplary space of heterogeneity (a specially demarcated bottom portion of a page) within an already heterogeneous whole (a newspaper) to denoting a genre in its own right, a genre in which these external relations of heterogeneity are becoming internalized and dialogized as a constitutive generic feature of the genre. So too, the perspectival dialogues between writers and readers that form the external set of relations of the newspaper become internal relations in the feuilleton, dialogized as an imagined familiar dialogue between the feuilletonist and the readership within the familiar space of the city.

What I will show in this chapter is how these two dialogic genres, dialogue and feuilleton, come to be emblematic respectively of the way the emergent intelligentsia both imagined its relation to the people as a problematic divide to be overcome by "getting to know" the people in dialogue, and the way the intelligentsia came to imagine the print public of Droeba as a kind of intimate dialogue between people already well-acquainted. The opposition between (transcribed) dialogue (with peasants) and feuilleton, I will argue, illustrates a shift from the "extroversion" of the intelligentsia in 1860s-1870s to the "introversion" of urban intelligentsia of the 1880-1890s. This external opposition between genres, I will show, is mirrored by the development of the feuilleton itself from a space on the printed page where dialogues with peasants can be represented ("the conversation in the feuilleton"), among a great many other things, to a genre in its own right dedicated to familiar, intimate dialogues between the urban intelligentsia ("the conversation of the feuilleton"). This parallels the way that transcription produces a serious, realistic, and embodied image of the peasant speaker that is 
opposed to the almost fantastic, playful disembodied image of the intelligentsia feuilletonist created by practices of pseudonymy.

Within the category of dialogues with peasants (transcribed "conversations in the feuilleton"), we will see how different possible ways of framing the relation between intelligentsia and peasant in conversation are explored: on the one hand, a transcriptive realism we have seen above which emphasizes and essentializes the alterity between the peasant and intelligentsia even as it seeks to bring these different voices together in dialogue; on the other hand, a liberal model of dialogue which instead emphasizes the substance of arguments over form and treats the status differences between peasants and aristocrats as an extrinsic historical predicament that prevents egalitarian dialogue in the present tense. The development of the feuilleton into a genre devoted to imagined dialogues between the feuilletonist and the readership (which happens relatively late in Georgia) instead draws our attention away from peasants in their villages to a self-conscious print public which is also a self-consciously urban intelligentsia. The focus of print culture in Georgia moves thus from dialogues with Orientalist strangers to dialogues with Occidentalist strangers, from the village to the city, from the peasant other to the intelligentsia self.

The very genres used to represent these two relations (both the opposition between transcription and inscription, dialogue and feuilleton) come to structure them in turn, producing finally a kind of unresolved and unresolvable contradiction between representations of the people and the public (or "society"), which are linked together by a notion of complementarity and service, but divided discursively. The sort of social totality I have been calling an "intelligentsia public" is very different from Western publics described by, for example, Taylor and Warner, which derive much of their potential for agency because they are identified with a kind of social totality (which is also understood to be sovereign in the ideal case), so much so that in English, "the public" is more or less understood to be the same as "the people" (whatever that described intentionally, which varies according to the variety of modern political imaginaries):

The public is a kind of social totality. Its most common sense is that of the people in general. It might be the people organized as the nation, the commonwealth, 
the city, the state, or some other community. It might be very general, as in Christendom or humanity. But in each case the public, as a people, is thought to include everyone within the field in question (Warner 2002, 49).

Warner connects the way that "partial publics" can become "the public" and thence function as a proxy for "the people" to the fact that publics are self-organized and that they are indeed publics of discourse.

[T] he modern sense of the public as the social totality in fact derives much of its character from the way we understand the partial publics of discourse, like the public of this essay, as self-organized. The way the public functions in the public sphere-as the people-is only possible because it is really a public of discourse. (Warner 2002, 51-52)

Both Western and tsarist publics make necessary discursive reference to "the people"; what is different is how the categories of discourse and the people are related and integrated into an imagined social totality.

In Western publics, there is a conflation of discursive category of potentially unlimited address (a public) with a universal category of discourse (the public) and thence to a social totality (the people). Warner argues that some publics are more likely to be conflated with "the public" because of their own universalistic claims to discussing "the people": "Some publics ... are more likely than others to stand in for the public, to frame their address as the universal discussion of the people" (Warner 2002: 82). Warner seems to equivocate here between what kind of universal discursive category "the people" are, whether they are what is addressed by such a public address, or whether they are what is discussed by such a public address. In either case, "the people" and "the public" are more or less understood to be different names for what amounts to the same referent, and that sense of referential identity is how they are constructed as being the same object.

Here is the difference: the intelligentsia public is, after all, universal like a Western public because it discusses "the people" (the object of the question "What is to be done?") in genres like ethnographic sketches or realistic descriptions of the voice of the people in dialogue. But at the 
same time, the "public" that is addressed, in the familiar dialogue of the feuilleton, is not imagined to include "the people" (though it is imagined to be in the service of the "people"). It is here that we find portrayals of the society of writers themselves, often playful, satirical, and always familiar or intimate. Thus, representations of the people and the public are found in different dialogic genres with opposed epistemic frameworks: realism versus satire, dialogue as an external relationship between utterances of different embodied speakers versus dialogism, dialogue as an internal relationship between writer and reader. The net result is what Herzfeld has called a "disemic" vision of a social totality divided between genres of official self-display and genres of intimate self-recognition (Herzfeld $1989,1997)$, between an official representation of the national self, the people, embodied in the peasant other, captured in ethnography, realistic descriptions of dialogue and folklore, and a familiar, intimate, smiling, satirical representation of the intelligentsia self.

This disemic opposition carries over into an opposition between two kinds of conversations found in the feuilleton: the reported, quoted dialogue with the peasant, the framed "conversation in the feuilleton," and the reporting, quoting dialogue with the reader, the framing "conversation of the feuilleton" (Morson 1981, 20). The former "conversation in the feuilleton" converts the peasant not, as perhaps intended, into a dialogic partner whose voice participates in the public debate, but rather into a framed, quoted voice, a kind of set of official representations of the people, what Frierson compares to an iconostasis (1993, 6, 194), that is the matter of intelligentsia debate, but not a participant. Rather, it is the containing genre, the "conversation of the feuilleton" between the writer and the readership, which can be about anything, that provides the reflexive meta-position for imagining the social totality of this particular variety of print public, the standpoint that Bavreli searched for by using the fantastic figure of the new technology of flight, the aerostat, a position which allowed him to survey the people invisibly from a dizzying height.

In Georgia, as in Russia, the attempt to "close the gap between educated society and the peasantry through personal experience and shared knowledge of the village was thus a reassertion of the polarity of Russian society [sc. between 'society' and 'the people']" (Frierson 1993, 194). Like an iconostasis, Frierson argues, these images of the peasant reproduced a division like that in a church between the sanctuary and 
the nave, the village and the world of educated Russians, but failed to produce the desired secular equivalent of the cosmological mediation provided by an iconostasis, to mediate this divide and join these two into a single social totality (which was the goal of the Georgian discourse of "getting to know" the peasant and its Russian equivalents). If the realistic ethnographic sketch is an idealizing iconostasis of the peasant, then the feuilleton is more like a caricature or cartoon-a smiling, parodic voice. In fact, the urban figure of the graphomaniac writer with pretensions to literary fame, the feuilletonist, whose writings obey not the realist strictures of knowledge or truth of ethnographic, but hiding behind a pseudonym which is both a protective mask and a literary celebrity, are smiling lampoons and satires.

\section{Boundary Work:}

Conversation in the Feuilleton and Conversation of the Feuilleton

The 1870s was a time in which the impulse to "get to know" the recently emancipated people of Georgia, or later in the decade, the recently reconquered people of Ottoman Georgia, was reflected emblematically in the reportive realism of the "conversation in the feuilleton." By contrast, the late 1880s and 1890s was a period in which, as the feuilleton itself moved from being a space in the newspaper characterized by an endless heterogeneity of genres to being a genre of heterogeneity in its own right, this extroverted impulse for knowledge of the peasant other became instead an introspective "conversation of the feuilleton," a dialogue between and about the urban intelligentsia.

These two genres of conversation and definitions of feuilleton coexisted in feuilleton section of Droeba throughout the period of the 1880s. The first example I have found of a "boundary work," a work that stands both on the boundary between these two different epistemes (reportive realism and familiar satire) and epistemic objects (peasantry, intelligentsia), these two kinds of dialogue and two different senses of feuilleton, dates from 1880. By "boundary work," I mean a work that stands on the boundary of these two (admittedly exaggerated) periodizations, but also a work in which "it is uncertain which of two mutually exclusive sets of conventions governs a work... [where] it is possible to read the work according to different hermeneutic procedures and hence, all other things being equal, derive two contradictory interpretations" (Morson 
1981, 48). This work, found in the feuilleton section of Droeba, 1880, number 246, at the bottom of the page separated by a black cutoff bar and labeled "Droeba Feuilleton, 21 November," and at the same time contains the word "Feuilleton" in its own title as a description of the genre: "Ajarian Feuilleton." This feuilleton is a "boundary work," a work that is a feuilleton in both the spatial and generic sense, as well as one that can be read both as a realistic, transcribed dialogue with the people and an imagined dialogue with the public, illustrating the two kinds of conversation I am talking about here, one quoted, one quoting.

In this feuilleton, the feuilletonist, writing, as feuilletonists always do, under a pseudonym (Ucnauridze "Stranger-son"), reports a conversation with an Ajarian Muslim Georgian. Unlike the usual member of the intelligentsia of the period, who runs chasing after a group of peasants in eagerness to know their minds and set down their words redolent with rusticity on paper, this one represents himself as minding his own business, resting under a tree, enjoying a peaceful moment of communion with nature, only to be rudely interrupted by the approach of an old Ottoman peasant. With mild irritation to have his reverie with nature interrupted, he reluctantly invites the peasant to take a seat beside him. When the narrator asks him what news (using the Georgian ambavi) he has, the Ottoman peasant complains that he, rather, should be asking the narrator for news (repeating the Georgian word ambavi and then substituting the Turkish word xambari):

—What will you tell me, grandfather, news? What news is there among you?

-News [ambavi]? You will know the xambari [Turkish, 'News', Georgian ambavi], who tells us anything, or the truth, in such godforsaken places? You read the newspapers of the world and you know everything ... I came to you to find out the news [xabrebi], what is the news [ambavi] in the world. How goes the affairs of our Padishah, does anyone threaten him with qavla (omi ['war'])? ${ }^{1}$

The peasant seems to know about the universe of circulation that is denied him. This is the first sign that this is a "boundary work," a boundary condition that seems to be emblematized by the use the Georgian word ambavi "news" in insistent juxtaposition with the Turk- 
ish synonym xambari. The feuilletonist responds that the peasant need no longer detain himself with worry over his former ruler, and the talk between them turns to whether the peasant intends muxajirat (emigration), again ostentatiously deploying a non-Georgian word, and if so, why? $?^{2}$ The conversation goes in this fashion, exemplifying an aesthetic of transcriptive realism, with both of them liberally littering their speech with Ottomanisms (almost all of which have some sort of specifically Muslim religious referent, drawing attention not only to alterity of language but alterity of religion as well between the interlocutors), each parenthetically glossed in Georgian. ${ }^{3}$

As in many such dialogues, the feuilletonist (reluctantly) assumes the mantle of enlightener, using various arguments to try and persuade the peasant that he should not engage in muxajirat. Finally, in an effort to overcome the deference implied by the way the peasant addressed him as aznauro "lord," the feuilletonist explains the new idea of egalitarianism, explaining, too, that he is no more than a peasant himself:

-No no, Lord (aznauro), for that we have a separate emri (brdzaneba ['command']) from Allah, that we must be on the land of the Padishah.

-Do not call me 'Lord', I am the child of a peasant like you, call me by my name.

-What for, is lord a bad word? We call anyone 'lord', who is a great man, or respected.

-No, grandfather, among us now it isn't like that, among us a lord and respected is that one, who eats bread won with his own sweat.

- Hahaha! He laughed with a pained smile, if it were that way, we would all be lords, I don't only sweat, I water my fields with sweat and in this way I barely bring enough cornmeal bread for my oghlu-shighi (col-shvili ['wife and children']). ${ }^{4}$

In the typical manner of a transcription of an aggrieved "voice of the people," the peasant is allowed a litany of sorrowful complaint, and the writer finally, perhaps impatiently, asks him, "If you don't let anyone know about your sorrow, how can anyone help you? Who knows anything about what pains you?" But this is where the conversation in the 
feuilleton becomes instead a conversation of the feuilleton. Because as the peasant announced when we met with him first, "Why ask me the news? You are the one who can read newspapers, I was going to ask you that!" so too, the peasant points out, that it would be difficult to imagine anyone in the writer's public who did not know about their problems, "Even the frogs in the water know about our affairs and if someone wanted to help, they couldn't find out?!" No, the peasant concludes, everyone (he means "of you, the readers") knows the problem, it is just that that no one cares. The intelligentsia dialogue with the peasant, both as speaker and listener, is over: "But today they won't let us speak and there are no godly men who listen to our sorrow."

This peasant seems somehow to know how much the readers know already, and the voice of the peasant moves from being a quoted voice of a conversation in the feuilleton to being the framing voice of the conversation of the feuilleton. This peasant is indeed well-informed and well-read, because, after all, the feuilleton section of Droeba, particularly in 1880 up to this point, was filled with reported conversations with Ottoman peasants, or otherwise reported the plight and flight of Ottoman, and specifically Ajarian, peasants. ${ }^{6}$ This particular feuilleton is the most reflexive of these, elevating the quoted voice of the peasant to a commentary on these quoting voices, using the device of the intelligentsia dialogue with the Ottoman peasant, in effect, to comment on the imminent demise of the dialogue with the Ottoman peasant. It is at this point, when the peasant's accusing gaze moves out of the quoted diegetic space and looks the reader full in the face, that the feuilletonist's description of this peasant's complaint is cut short, this time not because of a recalcitrant aristocratic scribe, but with a nod to the other party of their conversation, the censor: "Aside from this the old man spoke to me about many other things, whose description I will leave off because they wouldn't be printed"7

On one level, this dialogue is almost an exact replication of the genre established by Chavchavadze in Letters of a Traveler. The parallelism of the coda of this dialogue (with a nod to the censor) with a peasant with the coda of Chavchavadze's Letters of a Traveler (quoted above) is striking. There, as here, there is, of course, a thorough-going commitment to realistic depiction not only of the referential content ("thoughts" and "words") but also the specificity of form attendant to each ("thoughts" take on formal specificity (peri "color, form") as words of dialect (medi- 
ated by the technology of footnotes, or here, as bracketed glosses), so words in turn take on a further degree of specificity through distinctive accent (k'ilo) (mediated by technologies of transcription).

There, as here, exists a hierarchical organization of faculties (Warner 2002,89 ) in which rational-critical discourse is identified with the voice of the intelligentsia while the voice of the peasant is typified as a sorrowful voice of complaint, an emotional appeal to pathos (contrasted with the rational "enlightener" voice of the intelligentsia). The intelligentsia is interpellated by this peasant voice of complaint as, in some sense, servants of the people, people who hear the plaintive cry of the people, and who merely transcribe this inchoate, affect laden complaint for the public (and of course, implicitly translate it into a political program of action). The partners in dialogue (intelligentsia, peasant) are also parts of the social totality, which have distinct and complementary faculties (reason, woe) associated with them, resulting in a vertically organized Durkheimian "organic" solidarity of dissimilars with complementary functions, as opposed to the "mechanical" solidarity between fundamentally similar parts forming a "deep, horizontal comradeship" that is typical of the social totalities of a Western public (Anderson 1991, 7). There, as here, even this apparently neutral, objective, realistic transcription of the plight of the peasant cannot be completed, because the censor (the state) is also a party to this discourse.

But at the same time, where Chavchavadze was made into a "sharer in woe," this feuilleton is less addressed to sharing the woe of the peasant with the reader, but rather, since the readers will already know about this woe, accusing them of indifference. The end of dialogue with the peasant reflexively, metapragmatically announces the end of all dialogues with peasants. At the same time, as a "boundary work" (in more than one sense) it can be read as, and illustrates, two kinds of dialogue: a represented, quoted dialogue between the feuilletonist and the Ottoman peasant, and a representing, quoting dialogue, between the feuilletonist and his readers, a possibility which the writers draws attention to by titling his contribution "Ajarian Feuilleton." The former dialogue represents an act of turning toward the people, a dialogue of introduction (gacnoba), the second dialogue represents this as, in fact, a turning away from the people, a dialogue of farewell. What begins as an apparent exercise in realism, "getting to know" the Ottoman people, ends as a muted satirical critique of the intelligentsia, part of a dialogue 
with the readers of Droeba, accusing them of indifference to "getting to know" the peasant (illustrated, indeed, by the indifference, even mild irritation, of the narrator that he is forced to interrupt his reverie with nature to have this dialogue at all).

\section{Liberal Dialogues:}

Arguments about Equality and the Equality of Arguments

While Chavchavadze's Letters of a Traveler (1871) was perhaps the most influential model of realism applied to dialogue with a peasant, it was not, in fact, the first time either the device of travel letters, nor the device of dialogue between a member of the proto-intelligentsia and a member of the peasantry, had been used in this way. In the second year of Droeba (1867), on the very eve of the belated and drawn-out emancipation of the peasants in West Georgia (1865-1871), another writer had used the device of traveler letters and dialogue to explore these issues. The author of this letter was the Western-educated liberal writer Giorgi Tsereteli (writing anonymously), Georgia's "first professional journalist" and editor of many radical Georgian newspapers, including the founding editor of Droeba itself from 1866 to 1869 (Jones 2005, 39). Tsereteli was a member of the "second generation" (meore dasi) of terg-daleuli intelligentsia (following a genealogy proposed by Tsereteli himself) (Jones 2005, 37-8), referring to themselves as the axali axalgazrdoba ("the New Youth), which broke with the more conservative "first generation" terg-daleuli gentry nationalists like Chavchavadze in the Emancipation period (Suny 1988, 131, see Jones 2005 for Tsereteli's changing political position across multiple generations of Georgian politics).

The place of travel for these "travel letters" was West Georgia, including Imereti, Svaneti, and Mingrelia, and the author, unlike Chavchavadze, is not traveling a familiar terrain densely populated with the voices of other writers, however, he is traveling a terrain populated with the voices of nobles and peasants, with much to talk about. However, unlike the speech of Lelt Ghunia, which is so overwhelmingly clothed in "qualities of presence" that at times it becomes impossible to decipher, here the peasant speech, at least in its outward form, is no more or less intelligible with its Imeretian dialectisms than that of their noble interlocutors. The emphasis is not on the difficulty produced by formal alterity or authenticity of their speech, nor even on their voice as an inchoate 
affect-laden cry of woe and sorrow, but rather, an almost Habermasian concern for the referential content of arguments, what arguments can be made, and what arguments cannot be made, under what conditions, the difficulty of achieving egalitarian dialogue when the partners in the dialogue are not equals.

The world reported in these letters, written on the eve of the end of seugneurial Georgia, is one in which status differences between peasant and aristocrat registered in outward embodied signs, especially clothing, are of the foremost importance. Clothing also forms an important topic of conversation between Chavchavadze and Ghunia, there Ghunia prefers Georgian clothing to European clothing as an "outer" "visible" sign of "inner" "invisible" Georgianness: "In Russian dress a Georgian becomes a foreigner." For the narrator here, however, European clothing is preferable to Georgian clothing, preferable precisely because it displays at a glance the difference between noble and peasant. The political differences between Chavchavadze and Tsereteli can be seen in the semiotic value of European clothing: for Chavchavadze the semiotic value of clothing is located in the national question and demarcates national difference (Russian/Georgian), while for Tsereteli it is located in the social question and demarcates status difference (noble/peasant). Our author, an impoverished son of the gentry, is dressed badly: "I was dressed in a soiled white choxa [a distinctive Caucasian coat] of worsted wool." His filthy white choxa, like the fact that his mount is an old donkey, shows that he is gentry on the skids, potentially mistaken for a peasant. As for his companions, he briefly describes their much more respectable dress, with an apology to the reader as to why such picayune details are important:

Gigoliki was dressed in European clothing, and Chikoliki was wearing a red-collared Sartuki [Russian-style shirt]. Don't you wonder that I am talking about such trivial matters as these! — but inasmuch as they evaluate the man by his clothing here, for that reason it is not possible that I would not have said anything about it; all the more, because my poor clothing, as one from a lineage of boaster aristocrats, made me undergo considerable humiliation. In this region if someone is dressed in a European fashion, they will immediately conclude, 'this one must be without a doubt someone high-ranking." 
Clothing determines how you will be treated, in particular, what kind of hospitality you will receive as a traveler. If you are dressed well, particularly if you are dressed in European style, you will be recognized as a person of importance, shown respect and housed with a good host, "But if you are dressed in our fashion, simply [ubralod] and they recognize you as a simple person [ubralo in the sense of 'of low estate']," then God help you, they will claim no one is in and send you on your way to some other house: "In such circumstances, it is no wonder, that European clothing has great significance..."

He is treated no better, or even worse, by some of his noble traveling companions on this account. Even one of his traveling companions, an Imeretian nobleman with the pseudonym Kudabzika (a nickname derived from a term which basically means a "stuck up but on the skids" member of the gentry), who is riding a somewhat ratty horse, in principle no better than this own mount, is unhappy to be riding next to him, even though he knows him to be of aristocratic descent. He says nothing, because he knows our author is a noble like himself dressed as a peasant, but our writer can read his thoughts and recognizes his irritation and distaste to be seen riding next to someone dressed like a peasant. ${ }^{10}$ In fact, very little of what transpires between him and Kudabzika is registered in terms of actual speech, but is rather, like the "conversation of the feuilleton," an imagined, imputed dialogue based on intimate familiarity (very similar to the sort of intimate familiarity that Warner sees between the intimate strangers of a Western public). Our writer, based on his own intimate knowledge via membership in Imeretian nobility, comfortably populates Kudabzika's mind with insults unspoken, just as our writer records his own imagined retorts and other redressive actions that would be possible if he were dressed properly. Kudabzika cannot speak his insults directly and cannot call the writer a "peasant" (based on his dress) as he would like, because he knows the writer to be an aristocrat like himself. The writer, on the contrary, feels the implied insults as an aristocrat but cannot reply or take umbrage openly, because he is dressed as a peasant. The discord between their appearances is the occasion for their imagined dialogue, their shared status as aristocrats is both what permits it to be imagined and what prevents it from being openly articulated in words. Their conversation is a silent one of imagined slights and imagined retorts. 
How different then, are the many open conversations they have with the peasants. The first conversation begins as an attempt by an aristocratic guest to repay the peasant host's hospitality in food with words, specifically information about the coming emancipation. During their conversation that evening (before dinner) we learn, among other things, that Chikoliki, the leader of this band of travelers, is a blowhard who likes to talk about, indeed praise, the ideas and works of European authors he has never read, but has only read about in Russian journals and gazettes, and all this in extremely stilted and pedantic language. Summarizing at some length both Chikoliki's posturing and the more general malaise he represents, namely, the false sense of enlightenment and knowledge that comes from reading not the European authors themselves, but only reading a brief review of that author in a Russian gazette, represents a good half of this long letter. Having concluded that while perhaps in the future genuine knowledge and (European) enlightenment will arrive in Georgia, he contents himself with the observation that "For the time being, we are all Chikolikis."

But the fact that Chikoliki is a blowhard who likes to hear himself talk about things he knows of only secondhand is indeed an important part of the context for the first after-dinner conversation. Chikoliki likes to talk, and after being served a tasty meal, he wants to pay the host back in kind, "if not in deeds, at least in words." This was an area in which Chikoliki excelled: particularly inasmuch as he knew that the question of emancipation was very much of interest to the locals, and it was something about which they hungered for information: "They awaited the arrival of these changes impatiently, as a small child awaits Easter." Chikoliki, then, desirous of repaying his host's hospitality with words, "for this reason he began to talk about the emancipation of the peasants," announcing to the brother of his host that this would happen within the space of a year.

The attempt at egalitarian conversation, seeking to achieve reciprocity between guest and host by imparting useful information, cannot overcome the traditions of deference between aristocrat and serf. This man, Merekipe, is obviously pleased by this news but strains to hide his involuntary smile from his guests, and eventually with some effort controls himself, managing to replace the involuntary smile with a grimace of pain. Instead of expressing joy, he begins to complain that the end of serfdom will be a disaster. To each of Chikoliki's arguments that 
it will improve the lot of the peasantry, he instead foretells a story of gloom and doom. His reaction, of course, is partially because he wants more information and partially out of deference to his guest, whom he knows to be of aristocratic background: "He began to oppose Chikoliki on this matter because he wanted him to tell him more news, and at the same time he also knew, that Chikoliki was one of the masters and he was buttering him up."12 Finally, having met Chikoliki's confident predictions with one prophecy of doom and gloom after another, he concludes that at least "a man who has a good lord at least is protected from his enemies": "with these words he pretended to announce his grief at the end of serfdom; but it appeared from his happy face, that if Chikoliki and Zigoliki had not been there, he would have danced in the (Cossack style) lekur-bukna style." Somehow this mutual attempt at deference and ingratiation between guest and host, aristocrat and serf, ends up in a disagreement. Meanwhile, inspired by the topic, as if to illustrate the decisive role of status, two other peasants at the other end of the table manage to have an egalitarian conversational disagreement as to whether the replacement of direct seigneurial rule with the rule of government officials will be beneficial or disastrous, a conversation in which they take diametrically opposed positions and which also descends rapidly into name-calling.

Chikoliki's conversational foray, significantly, is part of an attempt to achieve reciprocity with his generous peasant host, his host having assuaged their hunger with good food, he hopes to assuage the peasant's hunger for good news. In this respect, Chikoliki is unlike other aristocratic guests of his time, for like one-sided conversations, so too one-sided hospitality is characteristic of the relationship between aristocratic guest and peasant host in pre-emancipation Western Georgia. Precisely this historical lack of reciprocity confronts them as a practical and actual problem in the next village, the village of Zubi. Zubi is a

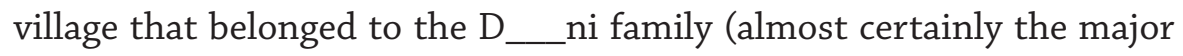
noble lineage Dadiani), who had apparently also been frequent, and rapacious, guests of the villagers:

[The lord D_ni] would come usually with forty, sometimes sixty, mounted men and a horde of people of this size would stay for two weeks or even a month. It was clear on the face of the Xelosani [village headman], 
how much an occasion for happiness was the coming of D_ni. . . . The xelosani of Zubi loved his merciful lord, much as a goat loves a wolf. It is not to be wondered that he was none too happy about our own guesthood, for he expected from us the same sort of mercy, as from his own lord. ${ }^{13}$

The hostility to these potentially rapacious aristocratic guests only changes when a smiling Chikoliki promises that he will repay their hospitality in turn "then the xelosani cheered up and swiftly found us everything we needed."

The theme of status inequality being registered in inequality of hospitality and conversation appears later, in the final letter, when a local member of the aristocracy (Bakura) meets his equal, a man, Giorgi the Svan, from the one area of Georgia that had always been "free": upper or "free Svaneti." The Svans are a high mountain-dwelling group speaking a language related to, but not mutually unintelligible with, Georgian, and within the next decade of Droeba Svans will quickly become a byword of obstinate backwardness and cultural alterity (a tendency found to this day in Georgia, where Svans are the protagonists of all jokes involving backwardness, barbarousness, and stupidity). This essentializing tendency to present Svans in terms of natural alterity is to some extent already present here in this piece, as Tsereteli likens the natural temperament of the Svans to the expressive properties of Enguri River, on whose banks in the laps of the mountains the Svans have settled the communes of "Free Svaneti": "The Svans are of the same sort of angry and savage nature, as the roaring Enguri River itself." ${ }^{14}$ Like the rest of his people, Giorgi the Svan is a free, proud man, but also perhaps more than a little "savage" (veluri) in looks and in personal habits (if the meat runs out, he sits down to eat the bones).

He openly shows his dislike for a young and equally proud local aristocrat named Bakura. Bakura is a listless young man of prodigious drinking capacity, one of those aristocrats who, though he has plenty of wine and food awaiting him at home, always manages to sniff out which peasant house is entertaining a guest, and as a matter of aristocratic privilege, always enlists himself as a sort of lieutenant host on the guest list: "perhaps he felt in his heart that the ill-mannered peasants cannot hold up their end in a proper conversation with a respectable guest, 
'therefore my presence there is required, that my courteous guest will not become bored."'15 Giorgi, as a proud, free Svan takes an instant dislike to this arrogant young noble leech, Bakura, and because he wishes to convey this distaste, he seats himself next to Bakura at the table, which he knows Bakura will not like, and hopes to enrage him with words.

'Alas, the lords really made a mistake when they freed the peasants. Now you have to hoe and do everything by hand yourselves.' These words were like thorns in the heart of Lord Bakura. He glared at Giorgi the Svan, looked to the side, spread out his hands and fiercely cried out: 'Look now at this goiter-afflicted Svan [Svans are conventionally associated with this affliction because of salt shortage]! Who asked your opinion about the emancipation of the peasants? ...'

-Yes yes!-Giorgi the Svan is a very freedom-loving man-Chikoliki cried out with a smile-He feels pain in his heart for the peasants, since he himself is free in his own land.

- That torn choxa and those muddy feet don't seem like freedom. Everyone has that kind of freedom. He is not free, our peasants are better than a goitrous Svan.

-Yeah, just because you are a lord [aznauri], how are you better. In my country I am an mdivanbegi [chief judge].

-Yes, Yes. I have him as my mdivanbegi. Chikoliki cried out, pleased with himself.

-If you were among us, if you were guilty of some offense, I would make you leave off that nobility of yours, I would catch you and lead you along in chains to the police captain-Giorgi the Svan told Bakura, laughing at him. ${ }^{16}$

This conversation does not get into the substance of the issue at hand, the emancipation of the serfs; that conversation can only happen between aristocratic peers secluded in the garden afterward. This is a conversation about the very possibility of a conversation between a lord and a peasant, albeit a free one, about this, or anything else. It all ends badly, Bakura storms off, and after Kudabzika's further attempt to 
have a conversation between peers with him about the emancipation in the courtyard, the whole thing ends in mutual name-calling, threats of violence, and nearly comes to blows. At the end, the peasant Giorgi is pleased he has gotten rid of the hateful aristocratic guest, but the visiting aristocrats decide it is time to high-tail it out of the village entirely, which is where this set of travel letters ends.

Taken as a whole, the point of each of these conversations is didactic; they are in effect a set of sophistic displays, represented by realistic conversations, designed to lay out the various arguments, pro and con, for different positions. They are not as much dialogues as dissoi logoi, a Greek sophistic practice, exemplified for example in Thucydides's History, in which for any given position two possible different opposing antinomic arguments are laid out. These are interested positions, so these arguments are associated with the sort of person (and attendant status attributes) who would make them in which kinds of contexts. Status inequalities or equality between conversational partners in turn become the metapragmatic theme of arguments, not because, as in Chavchavadze's Letters, they are registered in the form of the utterances, but because they are politically structuring conditions of the very possibility of dialogue: a peasant might not make the argument they wanted out of deference to an aristocratic guest, or might begin such an argument in order to please someone else or irritate someone. Because of the way they unravel and turn into fights, these conversations also remind us of what a precarious accomplishment is the newly won equality between lord and peasant, whether in matters of reciprocity between host and guest or in conversation. Attempts by Chikoliki to please his peasant host by news of emancipation run up against an impenetrable wall of seigneurial deference, while Bakura's aggressive and angry reaction to Giorgi the Svan's nettlesome remarks about the consequences of emancipation for the aristocracy remind us that such deferential behavior in the first conversation is not merely some habit of mind, but born in part out of fear of noble retribution. Conversation is represented in terms of its precariousness, in relation to deference and hospitality as well as in relation to the danger that it might descend into violence, even between status equals, let alone between lords and peasants, both those about to be freed, and those who have always been free.

The differences of representation of dialogue in Tsereteli's Travel Letters and Chavchavadze's Letters of a Traveler, composed independently 
in the same period, strikingly diagrams the political opposition between the liberalism of Tsereteli and the "new youth" and the sort of "Merrie Georgia" gentry nationalism of Chavchavadze and the Tergdaleuli movement (Suny 1988, 129, see also Jones 2005, 38-39). ${ }^{17}$ In Chavchavadze's Letters of a Traveler, there is a clear opposition between the folklorized speech of Lelt Ghunia and his modest transcriber, Ilia Chavchavadze. In Tsereteli's Travel Letters, there is essentially no difference between the speech of nobles, peasants, or indeed, the style of the narrator: Imeretian dialect prevails in the speech of all and sundry, and the device of the footnote is used as much to gloss the narrative text as noble or peasant dialogue. The differences between estates are not so much indexed in their embodied voice as in their embodied status (clothing, for example) that prevents them from being equal conversational partners. Unlike the realism of portrayal of the alterity of peasant speech in Chavchavadze's Letters of a Traveler, there is here no essentialized division between the embodied speech of the peasant, with nonstandard form and crawling with diacritics emblematic of its status as transcribed speech, and virtually identical voice/writing of the narrator, which both converses with, and comments upon, this subsumed folkloric voice of the peasant. In this sense, the dialogism of these letters might well be called a kind of "liberal" narrative of dialogue, in which status difference between aristocrat and peasant affects not the form of the utterance, but rather, the referential content, the political conditions of possibility of enunciation. In a similar way, clothing is not important because it expresses national specificity of form (as it is for Ghunia), but because it constitutes a visible sign of a social status that is an enabling condition for participation in such dialogue as an equal.

In a sense, the model of conversation in Tsereteli's Travel Letters is a familiar one within Western discourse, from Renaissance humanism to Habermas, in which conversation is treated as a model of political deliberation (Remer 2000, 2008). Tsereteli's conversations show, for example, the importance of freedom and equality of the participants in conversation (conversations are only possible between peers; between nonpeers, they become distorted). They also show the importance of the absence of coercion, not merely that of actual threats and violence, but also ethos (the status differential between aristocrat and peasant) but also pathos (strong emotions, particularly anger which leads to violence). Where deliberation does occur between peers (for example, 
between Kudabzika and the Bakura), the author attempts to present the arguments as being rationally motivated in terms of interests and not passions, though the fact of disagreement then leads to violent altercations (see Remer 2000, 2008). The historical predicament Tsereteli illustrates is one where the ideal model of conversation as deliberation can be enacted nowhere because of the pervasive distortions of extrinsic factors (ethos, pathos) that typify the historical "given conditions." At the same time, he preserves an essentially liberal model of conversation in which ethos or pathos are extrinsic, coercive, and distorting historical contextual factors which prevent the essential features of conversation as free, unconstrained, rational deliberation (about the end of serfdom) between free and equal, interested individuals from being realized.

By contrast, the model of "conversations with the peasant" of Chavchavadze's Letters of a Traveler and after does not serve as a model of rational, free, and egalitarian liberal political deliberation a la Habermas (on which, see Remer 2000, 2008). Nor again does it reflect a model of publics that are imagined as being in effect an intertextual enactment of such a dialogue (on the misrecognition involved in pervasive metaphors of publics as "conversation," see Warner [2002, 62-3, 68, 82-3] for an insightful critique). One important difference is the distinct role of ethos and especially pathos, which forms play an organic constitutive role in Chavchavadze's "conservative" dialogues (the rational intelligentsia becomes a "sharer in woe") and an extrinsic, distorting role in "liberal dialogues." In the former there is a linkage of the pathos of the people to intelligentsia action, which is very different from deliberative models of conversation, as Remer argues:

Even if you argue that decisions should be arrived at rationally, the impetus to act on your decision usually involves pathos. Accordingly, because political debate was destined to conclude in action, classical rhetoricians included the passions in deliberative oratory. Theorists of deliberative democracy, however, escape the link between emotions and action by de-emphasizing the role of action. Political debate, they imply, is about discussion, but this discussion need not culminate in activity. (Remer 2008, 192) 
Thus, the political moment of affect-laden conversations with peasants is predicated on an essential division and complementarity between the fully embodied, affect-laden urgency of the appeal of the peasant (containing both rhetorical appeals to ethos and pathos that are anathema to any liberal model of conversation, see Remer 2000, 2008), and the rational transcribing voice of the intelligentsia, who comes to understand the life and plight of the peasant and is moved to act. The way a hierarchical complementarity is established between popular affect (the transcribed voice of the peasant) and public reason (the transcribing voice of the intelligentsia) which are brought together in dialogue and within a single social totality in print should be contrasted with the way the same hierarchy of faculties between rational-critical faculties (elevated to universal attributes of humanity that allows discourse characterized by these properties to be treated as public or general) and (personal, private, or particular) embodied-affective ones, constitutes instead the opposition between Western publics and counterpublics (Warner 2002, 83-84, 89).

The orientation is not to dialogue as being self-valuable expression (as in models of conversational political deliberation (Remer 2000, 2008)) and publics that are imagined on the model of such dialogues (Taylor 2002, Warner 2002), but contains a certain urgency, an orientation toward action, toward "What is to be done?" The discursive complementarity between the aggrieved voice of the peasant and the rational intelligentsia much more closely resembles, for example, the way that the affect-laden pathos of feminine practices of ritual wailing in the Caucasus act unofficially as a kind of spur to action in men's political deliberations in politics of blood vengeance (for comparable oppositions in Ancient and Modern Greece, see, for example, Loraux 1986, 1998, Holst-Warhaft 1992, chapters 3-4, Serematakis 1991, chapter 7). ${ }^{18}$

\section{Conservative Dialogues:}

Realistic Dialogue and the Alterity of the Voice of the Peasant By contrast, after 1871, with the example of Chavchavadze's dialogues with Lelt Ghunia before them, and the strict injunctions of Umikashvili to transcribe the speech of the peasant precisely and authentically, representing the outer tradition garb of speech, the form and color of peasant speech, becomes as obligatory as representing the thoughts 
and words. The peasant was to be known through dialogues, indeed, the very process of "getting to know" (gacnoba) the peasant in general was best displayed by dialogues illustrating a specific instance of getting to know a peasant (usually beginning from a mutual exchange of greetings), in which the process of mutual recognition (including initial misrecognition) is often dramatized. In this period of the hegemony of an aesthetics and episteme of realism (which applied, of course, disproportionately to the representation of "the people" [see Frierson 1993]), represented dialogues needed to reproduce as much as possible the authentic embodied properties of peasant speech just as much as a folkloric text. Here Georgian writers (like their Japanese equivalents discussed by Inoue) "faced the stylistic question of how to entextualize linguistic excess, the sheer physicality and materiality of the human voice" (Inoue 2006, 85). This representation of this "linguistic excess" required development of a whole typographic technology of representation of the indexical, nonreferential material surplus of embodied speech, and borrowed heavily from the methodological strictures in folklore laid out by Umikashvili (1871) or the concrete example of the textual practices of Chavchavadze (1871).

The imperative for realistic portrayal of this linguistic excess, transcriptive realism, in some cases, ran up against the problem of unintelligibility, particularly among the even more unfamiliar peasants of Ottoman Georgia. Voloshinov comments with respect to the new taste for a "pictorial style" in representation of speech in nineteenth-century realism that the nonreferential indexical aspects of authentic character speech could render the referential content almost unintelligible, a tendency we certainly see in Chavchavadze's obsessive transcription of Ghunia's speech, where, as in the speech of Gogol's characters "character's speech sometimes loses almost all its referential meaning and becomes decor instead, on a par with clothing, appearance, furnishings, etc." (Voloshinov 1986, 121). This was a typical dilemma: one writer who reproduces many such conversations with Ottoman Georgian peasants, but without attending to the form of their dialect, begins his transcription of such a dialogue (which, of course, begins at the very beginning, with an exchange of greetings) with a note apologizing for and explaining their absence; the distance between their speech and his readers is simply too great to be represented. 
*) I beg the pardon from the reader, if I cannot report what the local people said in that dialect, the dialect [kilo] they were speaking, that is, the ma iulur dialect. They mix in a lot of Imeretian and Tatar words in their speech. ${ }^{19}$

Bavreli is generally quite assiduous in attempting to represent the speech of Ottoman populations. Since the lexical differences that need to be glossed are so many, he dispenses with the cumbersome device of footnotes used by Chavchavadze and simply inserts the Georgian gloss in parentheses (. . .) after each unfamiliar word (a device also used by Tsereteli to gloss Imeretisms in dialogue and narrative alike). For example, in one of a series of utterly banal conversations in a village where they stop at a qavaxana for the evening on their boat ride down the Choroxi, he talks to two boys who are playing. It seems the only purpose of the conversation is to show the alterity of their speech:

-What is it that you have in your hands?

—aia-oxia (shvild-isari [a bow and arrows])

-What do you want it for?

- qushi unda movk'la (prinveli unda movk'la [I want to kill birds] $)^{20}$

Bavreli's writings are littered with transcriptions of Tatar, Russian, Ossetian, Armenian, and Kurdish speech, partially attesting to his own multilingual repertoire. Bavreli's nearly endless transcriptions of diverse forms of Ottoman speech answer to demand for realism, answered by the painstaking and frequent representation of dialogue, as part of a desire to "get to know the peasant" to overcome the imagined gap between literate society and the illiterate folk in the early 1870 s in both Russia and Georgia (Paperno 1988, Frierson 1993), and the even greater gap between Russian and Ottoman Georgians at the end of the decade. In sharp contrast to the stance Tsereteli in the 1860s, who presumes a stance of existing familiarity and freely imputes hidden motives, left unsaid but perhaps expressed in nonverbal ways, to aristocratic and peasant others, the peasant is presumed to be unfamiliar and can be known only by the words actually spoken. Such realism based on external description of speech can reinforce the pervasive sense of 
unknowable alterity of the other. As Layton comments in her discussion of Tolstoy's realistic representations of mountain tribesmen, in revolt against the way that his Romantic predecessors like Marlinskii freely populated their "fiery tribal surrogates" with familiar knowable internal states, the description of Tolstoy confines itself to external facticity (including a new attention to the realistic description of tribesman speech using devices like pidgin Russian and interpreters): "The tribesman's mind remains terra incognita for the author ..." (Layton 1994, 248)

The realistic transcriptions of peasant voices, but particularly in the case of Ottoman speech, increasingly emphasize the alterity of that speech, and by extension, the alterity of the speakers. In the process of realistic transcription of form, the clear transcription of the open challenge to the aristocratic order represented by the articulate free peasant Giorgi the Svan in the 1860s becomes concealed behind an almost Aesopian language of realism of form in the speech of Lelt Ghunia. As Inoue comments with respect to the transcription of schoolgirl speech in early modern Japan "reducing the cultural significance of [schoolgirl] speech to its nonreferential aspect denies and repressed her referential voice, her will to mean and signify something in a rational manner. This is precisely a way of turning her speech into a 'fable' - she is speaking, but she does not know what she is saying. . . Alterity is, thus, tamed and contained not by being silenced but on the contrary by being allowed to be loquacious" (Inoue 2006, 54). In turn, the peasant finds in the voice of his intelligentsia dialogic partner a voice that is constructed as having all the opposite properties, a spoken voice essentially identical to the written voice of the narrator, a metalinguistic, reporting, quoting voice (representating a hegemonic "authority of anonymity") rather than a linguistic, reported, quoted voice (representing a subaltern "authority of authenticity"). Inoue's discussion of a homologous process in Japanese modernity is worth comparing:

In more concrete terms, the new narrating voice functioned at the metalinguistic level to signal that whatever it narrates, reports, describes, represents and states is true, real, serious and credible, and that it speaks not from a particular individual's point of view, but from the point of view of the modern rational and national (male) citizen-an omniscient point of view that purports not 
to be a point of view at all. This metalinguistic function was facilitated by formal (and diacritic) devices that separate the narrating voice and the narrated-whether it be people, events or things. Translating and appropriating the Western realist novel required ... writers to develop subordinated linguistic space in the form of dialogue and reported speech. This is a formal space where alterity is constructed, highlighted, and neatly kept apart from the self. (Inoue 2006, 92)

However, in the post-Emancipation period in Georgia, the device of realistic dialogue in this case is also motivated by a certain basic narodnik impetus (on which, more generally, see Paperno 1988, Frierson 1993, 38-47); it both constructs and highlights the alterity of the dialogic other, but it also represents a "going to the people," an attempt to overcome this alterity in dialogue. While the narrator does not usually adopt native garb in clothing or in speech (though in conversations with the even more "other" Ottoman Georgians, both Bavreli and other authors freely adopt or use Ottomanisms in their speech, indexing, along with their translations, their own multilingualism that enables their mediating role), the very act of placing themselves within the dialogue with the peasant allows the egalitarian writer to step down from their Parnassian metalinguistic heights and slum with the peasant in dialogue, moving from being the quoting footnoting voice of the folklorist to being one of the quoted (albeit not footnoted) voices in a dialogue. The peasant and the writer do not speak in the same voice, but the copresence of these different voices in the present tense of dialogue at least illustrates that they share the same time and space of Georgian modernity, an egalitarian move which serves to more strikingly illustrate their material inequality within that order. ${ }^{21}$

Strictly Entre Nous:

The Familiar Dialogue of the Intelligentsia Feuilleton

While the simultaneous consumption of the modern newspaper as print commodity, the "one-day best seller," imagined by Anderson expresses the sense of contemporaneity and reciprocity of perspectives between readers (Anderson 1991, 35), a newspaper like Droeba was the expres- 
sion of a public of readers who were also writers; most of the content of Droeba ultimately is written by its readers in the form of correspondence from different localities. Correspondence, both produced and consumed by the public, which forms the bulk of the newspaper and its characteristic genre, is a figure for the space-time of the newspaper's circulation, the way a newspaper assembles reports from distinct and possibly distant localities into a single space-time of contemporaneous newspaper consumers. But it is also a figure for the way the public of the newspaper is produced by readers in different localities who are also writers, whose writings always dialogic in that they anticipate a response from the other readers. Thus, the newspaper Droeba was a dialogic form as a whole, expressing a dialogue between readers who were also writers, a kind of dialogism typified initially by the genre of correspondence.

Anderson's classic account also emphasizes the way a newspaper as a genre creates an indexical icon of a homogeneous space-time of circulation by indifferently juxtaposing reports about distant contemporaneous events on a single page, the "imagined linkage" between them mediated temporally by calendrical coincidence of the events and spatially by the circulation of the newspaper within the space of a market (Anderson 1991, 33). But my focus on the centrality of correspondence to Droeba suggests that the space-time of circulation of such a newspaper is not internally homogeneous, and the space-times of Droeba are in part imagined on the basis of the uneven ground of the problematic material infrastructures, the channels, that mediate them. The newspaper is not only a kind of purely sociological assemblage of human voices, letters, and other correspondence; the genres of the newspaper also point to a sociotechnical assemblage of the various human and nonhuman, social, and technological actants (Latour 1992, 2005) that are combined into the "blackbox" of the finished product.

Infrastructures or channels of communication external to the newspaper become names for genres internal to the newspaper, each corresponding to a specific and distinct imagined space-time of circulation. I have already discussed two examples of this, correspondence and telegram. Correspondence, even if it was not specifically about roads and roadlessness (and this latter category was always topical), reminded the reader by its very existence of a spotty infrastructural network of the postal network, roads, and railways, as well as Ossetian postal riders and trains, from which it takes its name. Partly by virtue of the 
reflexivity of correspondence about its own infrastructural conditions of possibility, correspondence moves from denoting, in effect, a material infrastructural channel (answering the question of how this piece of writing arrived to be printed) to being treated as a characteristic genre of the newspaper, typically named as such and allocated its own specific space on the newspaper page, which points to an imagined local circulatory space-time of rural localities connected by this infrastructure. So too, the "telegram," usually printed on the upper left-hand side of the front page (see figure 5 above), is another genre named after an infrastructural channel which affords the imagining of still broader imperial and cosmopolitan space-times of circulation beyond the horizons of the local sphere mediated by correspondence.

Alongside these two space-times of circulation, the local or national (correspondence) and cosmopolitan (telegram), we find other genres in the heterogeneous assemblage of the newspaper pointing to other space-times of circulation. Announcements and advertisements for theatrical evenings in Tbilisi, occupying the same space on the printed page as telegrams, reminds us that the anonymous public of Droeba is also a largely urban aristocratic society (the other sense of sazogadoeba), anonymous contemporaries who are always potentially known face-toface consociates in the infrastructure of public sociability represented by the city and it theaters, cafés, and streets. Needless to say, this usually invisible world of the readers of Droeba is imagined in implicit or explicit contrast to the largely rural world mediated by correspondence. This is the world, after all, that Bavreli imagines as being equivalent to "that world" (the afterlife) when he is mired in the infrastructural limbo of Ardanuji.

The genre most characteristic of the space-time of the city, in contrast to the largely rural space-time of correspondence, is the feuilleton, a term whose changing meaning in this period illustrates a parallel transition from infrastructure to genre, channel to message similar to that found with correspondence. Originally, the feuilleton might be regarded as belonging rather more to the material, infrastructural order of the channel, it simply denotes a space in the newspaper dedicated to the heterogeneity of correspondence to the newspaper. The feuilleton quickly develops from a space for messages of heterogeneous genres to being a genre in its own right, a genre that is internally characterized by heterogeneity. In the space of the feuilleton, therefore, among all the 
various genres that might appear (including novels, poems, and other genres), two distinct genres pointing to different imagined space-times of circulation jostle with each other from the 1870s to 1890s. The earlier of these, characteristic of the 1870s, is the genre of correspondence, a genre associated with the imagined space-time of rural Georgia, whose object is transcription or description of the rural people ("conversations in the feuilleton"). The later of these, characteristic of the 1880s to 1890 s, is the genre of the feuilleton, a genre pointing to the emerging sense of a space-time of the city, a heterogeneous genre devoted to an equally heterogeneous object, whose object is an intimate dialogue between the urban intelligentsia ("conversations of the feuilleton").

As in Russia, the feuilleton originally designated a space at the bottom of the page, below a cutoff line, where virtually any sort of correspondence, in any genre, might be printed (Dianina 2003b, 254-5). From here, it became a genre unto itself, characterized by an internalized heterogeneity and satirical, "smiling voice," "predicated on a certain social intimacy between author and reader" (Dianina 2003a, 204), registering a familiar dialogic rapport within the intelligentsia:

Originally a journalistic miscellany in which disconnected items of the city's cultural life were presented, the feuilleton gradually became tied together by the loose and whimsical transitions of a digressive persona wandering from topic to topic-and sometimes, in the conventional role of flaneur, from place to place as well. The genre's subject matter was characteristically broad-so broad, indeed, that the problematic unity of the feuilleton because a theme for both feuilletonist and their critics (who sometimes attacked feuilletons in feuilletons). 'It is not necessary to explain what a feuilleton is,' observed one author ... (1843) 'Everyone knows what it is. A feuilleton is everything: theatrical reviews, stories, anecdotes, the chatter of drawing rooms, all kinds of odds and ends, a table laid with every type of excellent little things' ... As this heterogeneous list implies, almost the only topics excluded from the feuilleton were political ones forbidden by the censor-and so 'Aesopian' hints at the censorship came to have a place 
in this genre's testing of its ill-defined limits. (Morson 1981, 16)

All of these developments happened much earlier in Russia than in Georgia. The question arises: Why does this kind of intimate discourse, which could have been borrowed from the Russian example from the very start, seem to begin so late in Georgian newspapers? The feuilleton is, after all, an urban genre, in it is expressed the imagined community of the city, and thus, in order to understand its development, we need to look to the city of Tbilisi itself. Because the possibility of imagining an intimate conversation with a readership emerges when the proper historical "given conditions" have been achieved locally, that is, when a generation of readers have "grown old together" to form a reading community, when a city like Tbilisi and the intelligentsia has developed a large and sophisticated enough reading society and enough social events and locales beyond the life of the courtly circles to merit a flaneuresque appreciation. Certainly, this was a period in which Tbilisi was growing by leaps and bounds, its population growing from 78, 500 in the 1880s to 160,000 by 1897 (the population of Kutaisi in the Kutaisi guberniia [West Georgia] was at this time only 32, 492, Batumi 28, 512). By the end of the century, almost a quarter of the Tiflis guberniia (East Georgia) lived in Tbilisi itself, while in "backward" West Georgia only about 9 percent of the population lived in cities (Jones 2005, 13). It was precisely in this period that Tbilisi developed into the home of a self-conscious urban intelligentsia, which evolved its own specific urban mythology and urban genres of self-representation including the feuilleton (Manning and Shatirishvili 2011).

Of course, "given conditions" do not translate into social imaginaries automatically, there must be not only circulation, but also a reflexive imagining of that circulation. And who would be more qualified to imagine the development of the conditions of possibility of the urban discourse of the feuilleton than a feuilletonist? In a feuilleton on "Georgian literature [our enemies and friends]," ${ }^{22}$ the well-known feuilletonist Sano begins by asking his readers to recall the Georgian print culture of the 1870s, when universe of discourse of Georgian society (sazogadoeba) was much smaller. This was a period when the readership was still in its "apprenticeship," and dialogues happened between different writers in the press, as well as between readers in anticipation of the next install- 
ment of writerly dialogue, but the conditions did not yet exist for the internal dialogue between the feuilletonist and his implied reader that typifies the feuilleton:

Maybe you remember, reader, what sort of tendencies afflicted Georgian literature 10-15 years ago. Then Georgian society had one newspaper and two journals. . . . Then the greatest number and best readers were apprentices. These [apprentices] kept a careful eye on everything which 'Droeba', 'Mnatobi' or 'Krebuli' printed. I too, your most obedient servant, was one such apprentice-reader. From week to week the discussions of Georgian students were all about what Mr. Nikoladze wrote in response to Mr. Purceladze and we spent our time trying to guess 'Well, now, how will Mr. Purceladze respond to Mr. Nikoladze?'23

Certainly, one major change in the period is that as Georgian print culture expanded and these apprentice readers grew up, there was more to talk about each week than these political debates between two wellknown firebrands. Eventually, these external dialogues between actual "apprentice" readers discussing the contents of the press could mature to become internal dialogues between the feuilletonist and the imagined reader.

At the same time, on a broader imperial level, we are seeing the same transition here between the ethnographic period of interest in the peasant and the people in which the emerging intelligentsia defined itself in terms of its exoteric, official narrative of "What is to be done?" (in the 1870 s to early 1880s, the period of Droeba) to the self-absorption of self-defined, esoteric bohemian discourse of the urban intelligentsia of the 1890s:

When 'pathological pessimism over the muzhik [peasant]' had possessed educated society in the late 1880s, the question, Who is the Russian peasant?, was replaced in serious journals by the question, What is the intelligentsia? Attention shifted from the peasantry as the key to Russian culture and development to the educated, 
critically thinking elements of society as the decisive actors. Articles on the intelligentsia became as prominent as articles on the peasantry had been a decade earlier. (Frierson 1993, 189)

If the genre of "correspondence" is the one that typified the impulse to "get to know" the peasant, then the genre of feuilleton was that most fitted for the intelligentsia to define themselves. With the feuilleton as genre, the focus of interest moves from the village to the city, from the people to enlightened society, from getting to know the social other to an intimate discourse entre nous. The feuilleton was a collagelike genre that was essentially defined by describing the heterogeneity of a specifically urban context: the feuilletonist, like the correspondent, was a perambulatory figure, but his perambulations took place within the space of the city streets rather than on the ruinous roads of rural Georgia:

To deliver the most recent tidbits of news to his readership, the feuilletonist would run all over the city, hunting for mass gatherings and sites of entertainment, and then represent his findings in a manner that was moving and engaging. The resultant column, appearing regularly in the pages of the contemporary journal or newspaper, would offer a slice of urban culture: a collage of everything that has occurred in the area and that deserved mention, however passing. The feuilleton, in short, was 'everything: theater reviews, novellas, anecdotes, the chatter of drawing rooms - a true medley of all sorts of things, a table laid with every kind of glittering trinket.' (Dianina 2003a, 187)

The average feuilletonist of the Iveria period (beginning in 1885), for example, someone like Sano, whose column is labeled kartvelta shoris "between Georgians," spends most of his time talking about the discourse of newspapers (since now there is more than one newspaper), as above, or its sociospatial equivalent, the city and its typical inhabitant, the intelligentsia. Another feuilletonist, digressing (as feuilletonists always do, a feuilleton consisting of a series of digressions) to consider newspaper correspondence of past years, notes that much of it, 
amounting to little more than gossipy personal attacks carried out in public, lacked the "general/public" (sazogado) significance that made it appropriate to be published before society (sazogadoeba). Note the fluid way the feuilletonist imagines real and imagined conversations among the readers.

There was a time, when, in letters of correspondence sent from cities and villages, we would rarely read about any themes, other than those [devoted to] finding fault with, reprimanding, censuring and completely destroying someone. 'He committed this or that crime', you read it and you did not believe it; 'What is there here appropriate for a newspaper, what general (sazogado) significance does it have?' you asked yourself and you asked others. ${ }^{24}$

Feuilletonists are a form of life that could only evolve in close proximity to newspapers and cities. Even if the purview of the feuilletonist leaves the city, they may find themselves in some other city, and again, surveying the local intelligentsia, and not, for example, the local peasantry. ${ }^{25}$ The city forms the milieu and the purview of the feuilleton, just as the village forms the typical milieu and purview of correspondence. Where correspondence seeks to get to know the peasant other, the feuilleton seeks to define the urban intelligentsia self. While certainly no dearth of serious feuilletons were written under titles like "What Is the Intelligentsia?" it was perhaps more characteristic of the intimate satirical register of self-recognition of the feuilleton to approach the question of intelligentsia self-definition by satirically exploring pathological or defective versions of the type, such as the "useless intelligentsia" (laqe translated here as "useless" also has connotations of stupidity):

\section{$\langle$ Droeba's $>$ Feuilleton, 17 Oct. WEEKLY FEUILLETON}

... If you, Mr. Reader, were not born on the moon and have arisen on our native land, - of course, for better or worse, you must be familiar with that small portion of the intelligentsia, which among ourselves [shinaobashi] are called 'useless intelligentsia.' ${ }^{26}$ 
To external appearances, of course, the useless intelligentsia seem to be normal representatives of humanity, dressed respectably, even fashionably, in European clothing. No, to diagnose this person's problem, one must inspect this "man" more closely. Upon further inspection, his nature is found to be a monstrous hybrid, as if a series of different satirical literary personages from Russian and Georgian literature were mixed in a pot, boiled, and spiced with a generous helping of aristocratic arrogance (the term used is k'udabzik'a, a kind of arrogance whose personification is Kudabzika above) in custom and comportment. But the mongrel literary genealogy of the "useless intelligent" is due to the conditions under which he was conceived, a bastard love child of Europe and Asia, his hybridity instantiates as an unresolved contradiction the very oppositions Orientalist imaginative geography (Europe, Asia; progress, stasis; civilization, barbarism) which it is the historic role of the intelligentsia in general to overcome (bringing Georgia out of Asia into Europe).

From one side this [mixture] too is not surprising: the circumstances of his birth were such that it would have to have without a doubt resulted in such a creature. The civilization of Europe flirted with the ignorance of Asia, made eyes at her, smiled at her devilishly, lept at her and in the end seduced her completely to boot and from this illegal marriage was born this strange being, which . . . resembles neither its mother nor its father. It has an external appearance that is European, if not completely, at least to the extent that at first glance you can't detect anything [wrong with him]: he doesn't gobble raw meat, he doesn't try to eat the glasses, and so on; but as far as other internal, essential qualities of the European [are concerned],- - throw him back and go on your way. ${ }^{27}$

Since the essential property that characterizes a European is the property of being civilized, naturally, the opposite of Europeanness would be exemplified by characteristic acts of savagery, like eating raw meat or mistaking utensils for food. While this creature resembles a European only in exteriorities, more or less by not giving himself away with such acts of savagery, he does not resemble a "real Asian" either. Here, the 
concrete object of comparison, the "real Asian," is also, like the "imbecile intelligentsia" itself (and unlike the real European), a figure found locally in, and typifying, the urban context of Tbilisi, a (Azerbaijani) Tatar, a mutton-pilaf maker (a typically Asian—that is, Azerbaijani-as opposed to Georgian, food), in the bazaar of Tatar Square in Tbilisi, whose virtues are those of one locked in the stasis of tradition, specifically, because he knows his place and respects the authority of "society":

A Tatar, maker of mutton-pilaf, somewhere in Tatar Square, stands higher than this [useless intelligent] in this case. For one, the fact that this Tatar makes muttonpilaf, which, they say, is apparently pretty good-tasting, and in this respect he is bringing some small amount of utility both to himself and to others. Secondly, the same Tatar is at least intelligent enough that he cannot dare to blather publicly about those topics which do not concern mutton-pilaf and therefore exceed his knowledge and competence, he [knows he] cannot call white 'black' and cannot make black white. He cannot dare to show contempt for that which demands respect, nor respect that which demands contempt. He cannot dare to do this because he respects first of all [enlightened] society and secondly himself for his own part considers respect for both of these as a duty.

Such is a true Asian. ${ }^{28}$

The "useless intelligentsia" then lacks both the sympathetic respect for authority and tradition characterizing the true Asian or the enlightenment of a true European. But this character, surely, is an externalization and personification of the anxieties and internal disemia which characterizes the rest of the urban intelligentsia, which, after all, explicitly sees its civilizing role to overcome all the oppositions subtended by the imaginary geographic opposition between Europe and Asia (civilization; barbarism; progress, stasis; universality, national specificity, etc.). The "useless intelligentsia," the hybrid unintended product of the unchaperoned flirtation of European civilization and Asian backwardness, is the reverse image of this civilizing role. The useless intelligent manqué instead is a disemic figuration of fake enlightenment as a mere super- 
ficial imitation of external European appearances combined with a loss of national specificity, resulting in a rootless being that belongs neither to Europe nor Asia, but has the deficiencies of both. He combines the aristocratic arrogance of Kudabzika, the superficial empty enlightenment of Chikoliki, and the lack of respect for traditions and authority of a Nihilist. Through caricatured images like the "useless intelligentsia" in the feuilleton, the intelligentsia could explore, shinaobashi (entre nous, intimately, between ourselves, domestically) the repressed anxieties and doubts of the "real intelligentsia" about their own hybridity, their latent but repressed Oriental backwardness, and their incomplete assimilation of European civilization, and thus their own adequacy to their mediating role in the civilizing process.

The voice of the feuilleton belongs with other characteristics of this disemic intelligentsia discourse, specifically belonging not to the official extroverted register of respectable self-presentation, but belonging to the intimate register of self-recognition, it is a discourse that happens shinaobashi, that is, "indoors, at home, among one's own; domestically, internally." (Recall that Chavchavadze characterized the aristocratic manuscript circulation of lyric poetry of the earlier aristocratic writers as a literature that circulated shinaurobashi "among intimates, domestically"; the discourse of the feuilleton refashions this real intimacy between aristocratic consociates as an imagined intimacy shinaobashi between intelligentsia contemporaries within print culture.) The feuilletonist posits an intimacy between himself and the readers, but he is a stranger, albeit an intimate one: the feuilleton almost always is published anonymously (that is, pseudonymously [Mikadze 1984, 6]). The development of the authorial persona specific to this genre is strongly associated with the proliferation of pseudonymous personae, each feuilleton, becoming, in effect, an extension of the author's pseudonymous persona, which becomes in effect a kind of literary celebrity: "Although most feuilletons, particularly in the newspapers, were published anonymously, the personality of the author, with his individual literary background and ideological perspective, was blended into the potpourri of the narrative to such an extent that it made this inherently journalistic form of writing almost border on fiction" (Dianina 2003a, 194). In the same period, the device of the pseudonym, obligatory for a feuilletonist, becomes like Aesopian language, a way of enacting a disemic divide within the public between an exoteric public of official self-display and an 
esoteric public of intimate self-recognition. The same disemic tendency to move from extroverted "getting to know the people" to introverted "getting to know oneself" is exhibited in the opposition between the dialogue with the peasant, characteristic of the 1870s, and the imagined dialogue with the reader in the feuilleton of the 1880s. For the intelligentsia do constitute themselves by the socialist period with respect to the people in a quasi-disemic manner, between an exoteric, official nationalist narrative in which the intelligentsia form an organic unity with the folk within the nation, and an esoteric bohemian narrative in which the intelligentsia are sharply segregated from the folk, as I have argued elsewhere, there is

a central contradiction within the cultural ideologies of the intelligentsia between an 'exoteric' national narrative unifying the urban intelligentsia and rural folk and an 'esoteric' 'bohemian' narrative that kept these categories residentially and functionally distinct. . . . The intelligentsia imagined itself as being in a symbiotic relation to the people in ideal terms (from which it was separated in practical terms), and in practical terms it existed in a symbiotic relation to the state (from which it distantiated itself in ideal terms) (Manning 2009c).

The opposition between the reported dialogue with a peasant (usually within a letter which is itself in the feuilleton space of the journal) and the imagined conversation with the reader of the feuilleton genre parallels the disemic opposition between the official nationalist narrative in which the intelligentsia seeks to overcome the social divide with the peasant, and the unofficial bohemian narrative of intimate selfrecognition of the urban intelligentsia. 